\title{
OPEN
}

Published online: 24 December 2019

\section{Publisher Correction: Functional genomic characterization of metallothioneins in brown trout (Salmo trutta L.). using synthetic genetic analysis}

\begin{abstract}
Josephine R. Paris \& Jane Usher
Correction to: Scientific Reports https://doi.org/10.1038/s41598-019-48303-0, published online 14 August 2019

The Acknowledgements section in this Article was omitted. The Acknowledgements section should read:

"We would like to thank the Environment Agency, Westcountry Rivers Trust and the University of Exeter for the funding and support of Dr Paris' PhD project on trout metal tolerance. Particular thanks to members of the Environment Agency and Westcountry Rivers Trust for organising permits for electrofishing, fieldwork and collection of trout tissue used in the experiments. Thanks also to Dr Jamie R. Stevens and Dr Eduarda Santos for conception of the $\mathrm{PhD}$ project, and also to $\mathrm{Dr} \mathrm{R}$. Andrew King, who assisted with gene identification and molecular laboratory work."
\end{abstract}

\begin{abstract}
(c) (i) Open Access This article is licensed under a Creative Commons Attribution 4.0 International License, which permits use, sharing, adaptation, distribution and reproduction in any medium or format, as long as you give appropriate credit to the original author(s) and the source, provide a link to the Creative Commons license, and indicate if changes were made. The images or other third party material in this article are included in the article's Creative Commons license, unless indicated otherwise in a credit line to the material. If material is not included in the article's Creative Commons license and your intended use is not permitted by statutory regulation or exceeds the permitted use, you will need to obtain permission directly from the copyright holder. To view a copy of this license, visit http://creativecommons.org/licenses/by/4.0/.
\end{abstract}

(C) The Author(s) 2020 